\title{
Combining measurements, models and decision support systems to optimize outfall sitting
}

Tobias Bleninger / Alex Falkenberg / Alexandre Trevisan / Maria Olívia Maranhão / Mayra Ishikawa / Pedro Ribeiro / Rodrigo Barletta

DOI 10.4322/dae.2016.013

\section{ABSTRACT}

Santa Catarina Island is located in Southern Brazil and is a touristic spot of the country due to its beautiful beaches. Population growth and seasonal variability demand an improved sanitation system, to be provided by the local government. This paper presents the methodology used to define the optimal design for the wastewater management system for the northern part of the Island. TOPSIS methodology was used to rank the 42 possible alternatives. Subsequently, a 3D hydrodynamic model was implemented which was calibrated and validated for one year using measured oceanographic data. Afterwards, a near-field model was used to evaluate the dilution of each location and to set up the input concentration data for the far field water quality model to analyze the dispersion of nutrients, BOD and bacteria in order to assess each alternative regarding the environmental legal requirements. Results show that the method was able to find optimal solutions out of dozens of alternatives, and thus provides guidance to decision makers, sanitation and environmental agencies, and stakeholders.

Keywords: field measurements, hydrodynamic models, near-field, far-field, TOPSIS, outfall, discharge, water quality

\section{RESUMO}

Localizada ao sul do Brasil, a llha de Santa Catarina é uma atração turísticas do país devido suas belas praias. O crescimento populacional e a variação sazonal exigem o aperfeiçoamento do sistema de saneamento, proporcionado pelo governo estadual. $O$ artigo apresenta a metodologia para definir a melhor configuração para o gerenciamento do sistema de águas residuárias da parte norte da Ilha. A metodologia TOPSIS classificou as 42 alternativas possíveis. Na sequência, o modelo hidrodinâmico 3D foi implementado, calibrado e validado para um ano a partir de dados oceanográficos medidos. Posteriormente, um modelo de campo próximo foi utilizado para a avaliação da diluição de cada local, e para definir a concentração dos dados de entrada do modelo de qualidade de água no campo afastado, a fim de analisar a dispersão de nutrientes, DBO e bactérias para determinar a performance de cada alternativa de acordo com as condições legais do meio ambiente. Os resultados mostrem que a metodologia apresentada foi capaz de identificar soluções otimizadas e assim servir para tomadas de decisão.

Palavras-chave: medições em campo, modelos hidrodinâmicos, campo próximo, campo afastado, emissário, descarga, qualidade de água 
Tobias Bleninger, Dr.-Ing. and Dipl.-Ing. Civil Engineering, Karlsruhe Institute of Technology, Germany. Professor for Environmental Fluid Mechanics at the Federal University of Parana (UFPR). Caixa Postal 19011, 81531-990 Curitiba - PR, Brazil. Tel.: +55/41-33613212, http://www.tobias. bleninger.info, tobias.bleningeragmail.com

Alex Vieira Falkenberg, M.Sc. Numerical Methods in Engineering/UFPR, M.Sc Coastal Oceanography/UFPR, Control and Automation Engineer/UFSC, Project Manager at CB\&l Brazil. Rodovia José Carlos Daux, 8.600, Bloco 3, Sala 102, 88050-000 - Florianópolis, SC, Brasil. alex.falkenbergacbi.com Alexandre Trevisan, M.Sc. Chemical Engineering, Santa Catarina Federal University (UFSC), Brazil. Engineer at the Santa Catarina Water and Sanitation Company (CASAN). Rua Emilio Blum, 83, CEP 88020-010 Florianópolis - SC, Brazil. atrevisana casan.com.br...

Maria Olívia Maranhão, M.Sc. Marine Geology, B. Oceanography, Oceanographer at CB\&l Brazil. Rodovia José Carlos Daux, 8.600, Bloco 3, Sala 102, 88050-000 - Florianópolis, SC, Brasil. olivia.amatoacbi.com.

Mayra Ishikawa, M.Sc. Water Resources and Environmental Engineering, B. Eng. Environmental Engineering, UFPR, mayraishikawaDgmail.com Pedro Ribeiro, M.Sc. Geography, B. Oceanography, Project Coordinator at CB\&I Brazil. Rodovia José Carlos Daux, 8.600, Bloco 3, Sala 102, 88050-000 - Florianópolis, SC, Brasil. pedro.ribeiroacbi.com.

Rodrigo Barletta, Dr. Environmental Engineering, MSc Quemical, Physical and Geological Oceanography, B. Oceanology. Project Manager at CB\&I Brazil. Rodovia José Carlos Daux, 8.600, Bloco 3, Sala 102, 88050-000 - Florianópolis, SC, Brasil. rodrigo.barlettaacbi.com

\section{INTRODUCTION}

Despite of coastal water quality problems being studied since decades and solutions exist for their mitigation, major large water projects in coastal regions, such as marine outfall systems and wastewater treatment schemes are experiencing considerable delays in commissioning (Bleninger, 2012). For example, objections in Australia and the USA regarding environmental impacts have already become key issues for project permits, often considerably influencing plant commissioning and design (e.g. Huntington Beach, or Carlsbad, www.carlsbaddesal.com), and thus overall project costs. Henry Salas, formerly of the Pan American Health Organization (PAHO) showed in his keynote at the International Symposium on Outfall Systems in Mar del Plata, Argentina (see IAHR/IWA Joint Committee on Marine Outfall Systems, and Bleninger and Roberts, 2012) that many coastal wastewater projects in Latin America did not yet conclude their outfall system. More than 10 large-scale projects (each more than 1 million population served) were mentioned where almost completely raw sewage has been continuously discharged at the shoreline for more than 10 years due to these delays. Such problems of water projects seem to be mainly related to political and administrative problems, but often also to poor understanding of those systems.
There is often a misconception that treatment results in a 'pure' and 'clean' effluent which can be discharged directly on the shorelines or beaches. However, bacteria concentrations even of tertiary treated effluents are still order of magnitudes above bathing water limits (see Table 1).

Table 1: Discharge concentrations and ambient standards in comparison with required dilutions according to typical concentration reductions of treatment levels. Source: Bleninger (2006) - Adapted

\begin{tabular}{|c|c|c|c|c|c|c|}
\hline & 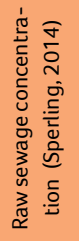 & 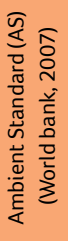 & 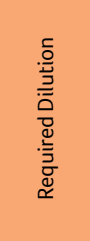 & 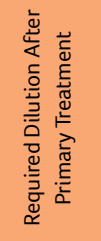 & 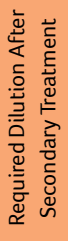 & 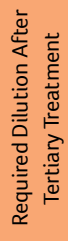 \\
\hline BOD [mg.L-1] & 300 & 30 & 10 & 8 & 2 & 1 \\
\hline $\begin{array}{l}\text { Total Nitrogen } \\
{\left[\mathrm{mg} \cdot \mathrm{L}^{-1}\right]}\end{array}$ & 45 & 10 & 5 & 4 & 4 & 0 \\
\hline $\begin{array}{l}\text { Total Phos- } \\
\text { phorus [mg. } \text { L-1 }^{-1} \text { ? }\end{array}$ & 7 & 2 & 4 & 3 & 3 & 0 \\
\hline $\begin{array}{l}\text { Total sus- } \\
\text { pended solids } \\
{\left[\mathrm{mg} \cdot \mathrm{L}^{-1}\right]}\end{array}$ & 1100 & 50 & 22 & 9 & 3 & 1 \\
\hline $\begin{array}{l}\text { Total Coliform } \\
{\left[\begin{array}{c}\text { MPN. }(100 \\
\left.\mathrm{mL})^{-1}\right]\end{array}\right.}\end{array}$ & $\begin{array}{c}- \\
10^{10}\end{array}$ & 400 & $\begin{array}{c}25000 \\
- \\
2.5 \times 10^{8}\end{array}$ & $\begin{array}{c}1250 \\
- \\
1.25 \times 10^{7}\end{array}$ & $\begin{array}{c}10^{3} \\
- \\
10^{7}\end{array}$ & $\begin{array}{l}500- \\
5 \times 10^{6}\end{array}$ \\
\hline
\end{tabular}

Dilution is herein defined by the concentration decay of a solution by the increase of its solvent. It happens when a wastewater treatment effluent is discharged by an outfall. The dilution of a conservative effluent (no decay processes) in an 
environment with a background concentration is defined by:

$$
S=\frac{c_{0}-c_{a}}{c-c_{a}}
$$

Where the dilution $S$ is dimensionless, $c_{0}$ is the concentration of the solution that will be diluted (in this case the effluent concentration), $c_{a}$ is the ambient background concentration and $\mathrm{c}$ is the observed or required concentration (after the dilution, or ambient standard).

Consequences of the misconception are thus often overly expensive wastewater systems, which themselves not necessarily solve the water quality problems. This happens when either the technology blend of the system (treatment and outfall) is not properly designed or further pollutant sources (such as drainage systems with illegal sewer connections or diffuse sources) were not considered in the whole scheme. Thus, purely treatment based solutions oversee the potential and necessity for a more holistic approach. The trend is clear, however, and should not be about competing systems but blended system with optimized combination of collection, treatment, and disposal.

The objective of this article is to illustrate how decision-making processes can be based on hard facts and objective analysis for choosing the best technology blend for wastewater management systems in coastal cities.

\section{METHODOLOGY}

The methodology used is a tiered approach starting with i) a screening phase to define feasible alternatives (see below), followed by ii) a measurement phase characterizing the current situation and boundary conditions (next chapter). The phase of field studies is complemented in parallel with the development and calibration of numerical models representing the current situation (basecase). In a third phase iii) all scenarios are simulated (third chapter) and analyzed in a fourth phase regarding their iv) compliance with environmental and cost-benefit criteria.

The environmental guidelines used in this study are based on Brazilian legislation, namely Conama $357 / 2005$, supported by Conama $274 / 2000$ and amended by Conama 430/2011.

\section{SANTA CATARINA ISLAND}

Santa Catarina Island is located in the Florianópolis municipality, capital of the State of Santa Catarina in south Brazil. It has an area of approximately $425 \mathrm{~km}^{2}, 54 \mathrm{~km}$ length from north to south and 18 $\mathrm{km}$ width (Figure $1 \mathrm{~A}$ ). The island has a population of 589,720 inhabitants, which can reach almost 1 million during the summer (IPUF, 2007); Florianópolis is well known as one of the major touristic attractions of the south of Brazil, mainly due to its beautiful beaches and landscapes. Besides tourism, fisheries and aquiculture represent important economic activities, since Santa Catarina is the national leader on oysters and mussels' production. Therefore, Florianópolis bays are important contributors (Santos \& Costa, 2014). The city is surrounded by several important environmental preservation areas such as mangroves, dunes and islands, especially the Arvoredo marine biological reserve located $10 \mathrm{~km}$ north.

In 2010 , only $39 \%$ of the population was attended by wastewater service, which could drop to $26 \%$ in the summer season (PMF, 2011). CASAN targets to designate significant investments in order to have 100\% wastewater service until 2030.

This paper focuses on solutions for the northern part of the island (Figure 1B), where the hot spots for touristic and aquaculture activities are located, and where coastal pollution problems a more severe.

\section{SCREENING OF ALTERNATIVES}

In order to support the decision making process to define the optimal design for the outfall system (collection, treatment, disposal), there were con- 
sidered several relevant factors such as the current sanitation infra-structure, population growth estimation, social aspects, cost analysis and potential environmental impacts. There were considered three different wastewater treatment systems: primary, chemically enhanced primary and secondary treatment, followed by either a short or long outfall at three potential locations (Canasvieiras, Ingleses and Rio Vermelho, Figure 1D), resulting in 42 possible alternatives. In order to evaluate the alternatives, the TOPSIS methodology (Aruldos et al., 2013) was applied, which represents a multi-criteria decision making approach based on similarity to an ideal solution (Falkenberg et al., 2016). The results showed (in detail in Falkenberg et al., 2016) that the TOPSIS criteria ranked three best alternatives overall and the best alternatives for each location to be evaluated in more detail with field-studies and near field and far field numerical modeling.

Regarding engineering, social, environmental and economic aspects, the following criteria were considered:

- Construction site access (engineering) $\rightarrow$ evaluate the difficulty of pumping wastewater effluent from treatment plant to ocean disposal site;

- Influence on aquaculture (social and environmental) $\rightarrow$ linear distance between diffuser to aquaculture area;

- Initial dilution potential (engineering and social);

- Proximity to Arvoredo Marine Biologic Reserve (environmental);
- Wastewater Treatment solution (environmental)

- Coastline plume proximity (social);

- Construction complexity due to depth (engineering);

- Global Outfall cost (economical);

- Global cost regarding wastewater conveyance from main wastewater treatment plant(s) to outfall (economical).

In order to attribute scores to each criterion referred to each alternative, the state sanitation company CASAN (Companhia Catarinense de Águas e Saneamento) invited 43 employees from different company areas, including environmental, technical, management, economical and operation sectors, which results indicated that several individual outfall systems were not cost attractive, corroborating Roberts et al. (2010), and the best ranked solutions over all were:

- Rio Vermelho: long, secondary treatment;

- Rio Vermelho: long, chemically enhanced primary treatment;

- Rio Vermelho: short, secondary treatment.

- The best alternatives for each location were:

- Canasvieiras: long, secondary treatment;

- Ingleses: long, secondary treatment;

- Rio Vermelho: long, secondary treatment. 


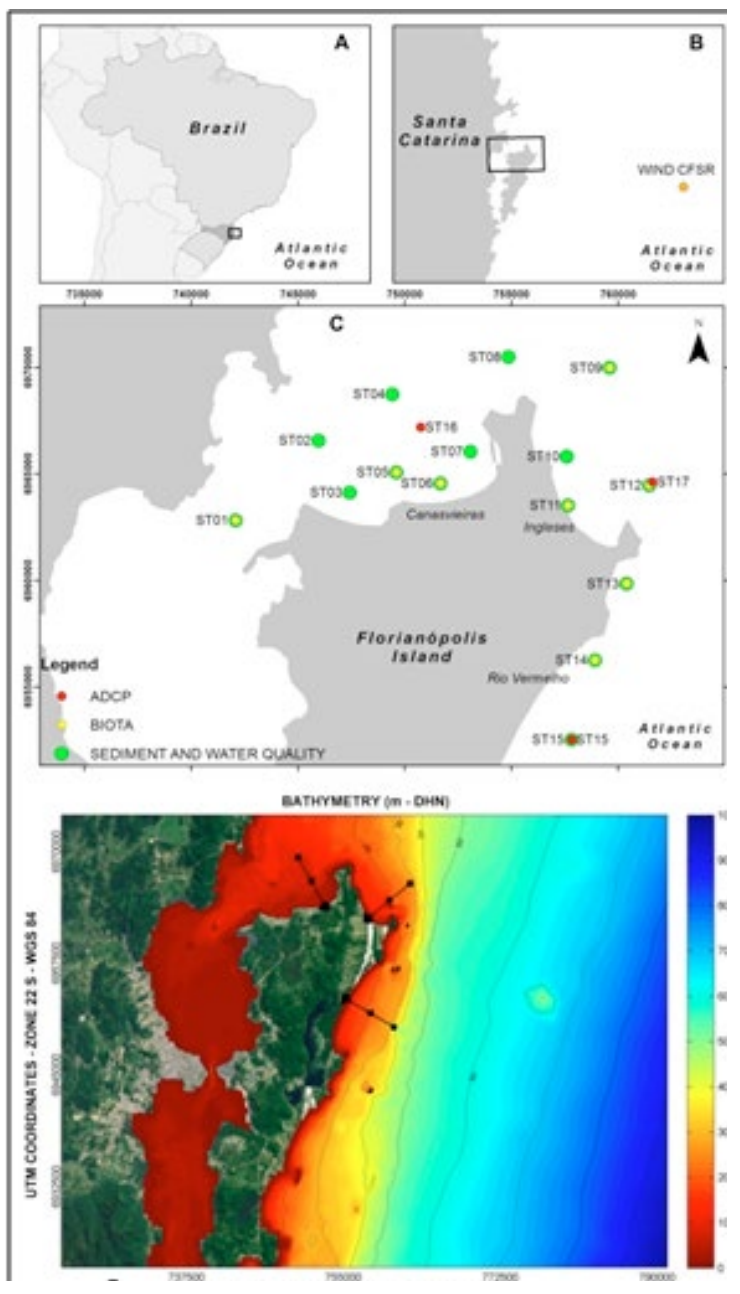

Figure 1: A - Location of Santa Catarina Island. B -North of Santa Catarina Island. Figure also shows wind data location. C - Locations of data sampling. Red dots for ADCP stations (current profile, temperature at depth, wave and sea level). Green dots for Sediment and water sampling stations. Yellow dots for biological samples. . D- Possible locations of the submarine outfall system (black lines and dots) and bathymetry (UTM Projection, Zone 22s, WGS 84).

\section{FIELD MEASUREMENTS}

Large and intensive field studies have been performed by CB\&l under contract of CASAN (Barletta et al., 2016). Biological, chemical and physical parameters were analyzed at over 15 stations (see Figure 1C), comprising two campaigns per season. Aiming to characterize physical oceanographic conditions measurements during more than one year were performed to understand the behavior of waves, tides, currents and wa- ter properties. Therefore, three ADCPs (Acoustic Doppler Current Profiler), one for each proposed location (ST15 - Rio Vermelho, ST17 Ingleses ST16 Canasvieiras, see Figure 1C) were deployed. Deployment depths were approximately 28,13 and $16 \mathrm{~m}$ respectively. These devices were installed on the seabed inside a structure with the transducer facing up (upward-looking) in order to perform measurements of the vertical velocity profile ( $1 \mathrm{~m}$ per cell) and measuring the waves with an AST sensor, sea level with a pressure sensor, as well as temperature. The ADCPs were configured to acquire information at 30 minute sampling interval. For measuring wave, data was acquired for 20 minutes at every hour in an acquisition rate of $2 \mathrm{~Hz}(0.5 \mathrm{~s})$.

The analysis of currents (see Figure 2B) for ST15, the most exposed station located at Moçambique's beach inner shelf, shows that the average directional axis of the water column flow measured was $15^{\circ}$ from the north, aligned to local isobaths. The maximum speed of the integrated current reached $0.77 \mathrm{~m} / \mathrm{s}$, however $75 \%$ of the analyzed data were equal to or below $0.21 \mathrm{~m} / \mathrm{s}$ with the average velocity of currents of $0.15 \mathrm{~m} / \mathrm{s}$. Over $57 \%$ of current measured occurred from northern to the southern quadrant (average of $184^{\circ} \mathrm{N}$ ). Forty three percent (43\%) of current occurred in reverse direction (average of $27^{\circ} \mathrm{N}$ ). The mean axis of movement of the current happened between $8^{\circ}$ and $22^{\circ}$, where the direction of the prevailing flow varied between measurement periods. In general the currents from south to north measured were associated with cold front events, while the flow in the opposite direction was observed for intervals between these fronts. The greater intensity currents were observed in winter with the average speed of $0.21 \mathrm{~m} / \mathrm{s}$, while the less intense were measured in summer, with an average speed of $0.09 \mathrm{~m} / \mathrm{s}$.

At ST16 there was flow predominance from northeast to southwest, recorded in $55 \%$ of the mea- 
sured currents, to an average direction of $226^{\circ}$. Conversely it was found $45 \%$ of the measured data, flowing towards a direction of $56^{\circ}$, resulting in a mean axis of the current of $51^{\circ}$. The maximum speed of the mean currents along the water column reached $0.49 \mathrm{~m} / \mathrm{s}$, however $75 \%$ of the data were below $0.15 \mathrm{~m} / \mathrm{s}$ with an average rate of 0.11 $\mathrm{m} / \mathrm{s}$. The pattern of currents was similar in all layers of the water column and differences between bottom stream velocity and surface are higher for currents from southwest to northeast (ebb tide) than for northeast to southwest (flood tide). The greater intensity was observed in summer and the slowest in spring. The mean axis of movement of currents varied between $48^{\circ}$ and $53^{\circ}$.

The annual pattern of currents for ST17 (Ingleses) showed dominant axis from northwest to southeast at an approximate average of $112^{\circ}$, present in about $60 \%$ of the data. Forty percent $(40 \%)$ of the remaining data showed the reverse direction, with a flow towards $316^{\circ}$, resulting in an average axis of $124^{\circ}$. This station showed the most intense currents, reaching maximum speed of $0.81 \mathrm{~m} / \mathrm{s}$. However, $75 \%$ of the data presented magnitudes equal to or less than $0.25 \mathrm{~m} / \mathrm{s}$, with an average speed of $0.18 \mathrm{~m} / \mathrm{s}$. The middle axis of movement of the currents ranged between $121^{\circ}$ and $125^{\circ}$, aligned with the morphology of the seabed. The direction from the main stream was from northwest to southeast, except for the autumn.

For the meteorological characterization, the directional distribution of the winds offshore Florianópolis was obtained through CFSR reanalysis data (Saha et. al, 2010) for the period between 2001 and 2014. Seasonality of fourteen year of data was then compared with the seasonality of the year for what measurements were performed (2013 to 2014). Figure 1B shows CFSR coordinate used to extract wind information.

The wind analysis results show the predominance of the northeast winds with a larger number of occurrences from this quadrant, although winds from south and SW show the higher intensities. The accumulated directional distribution for the monitored year for the present work are shown in Figure $2 \mathrm{~A}$ and showed to be very similar to the data set of 14 years. Extreme events occurred almost exclusively with southern and southwestern winds. The results agree with previous climate descriptions for the area. Figure 2B illustrates 2014 currents integrated at the water column for each sample station.

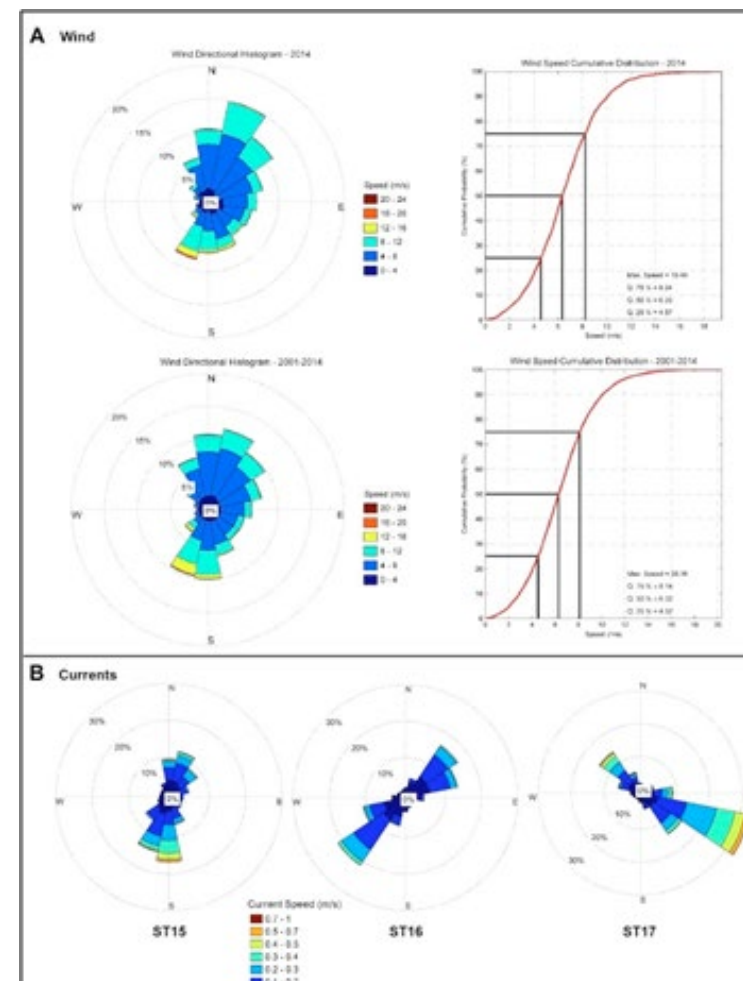

Figure 2: A- Analysis of wind measurements. B-Measured coastal currents at the three potential outfall locations.

Figure 3 shows an example of the processed tidal data of all seasons for sampling station ST15 (Moçambique). Meteorological tide is represented by the red lines. In general terms, the tide is mixed with predominance of semi-diurnal tides with inequalities of height and also diurnal variations $(0,25<$ Courtier $<1,5)$, micro tide system of the order of $1 \mathrm{~m}$. The data is in agreement with literature about the "Meteorological tide", that plays an important role to sea-level variations at southern 
Brazil (and also as upwelling mechanism), which causes sea level oscillations from $-60 \mathrm{~cm}$ to $60 \mathrm{~cm}$ around mean sea level. To separate the meteorological tide from the sea level data and to calculate the Courtier number a harmonic analysis was carried out (Barletta et al., 2016).

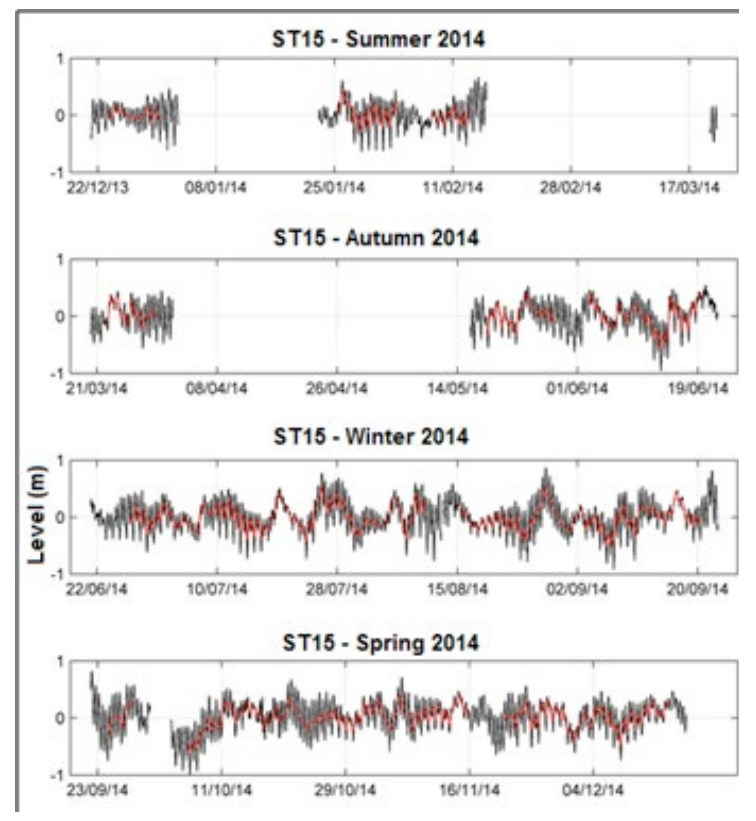

Figure 3: Example of tidal signal for ST15 (in red meteorological tide).

To obtain vertical profiles of salinity and temperature, CTDs were used at the campaigns. Measurements of salinity and temperature profiles were performed at 15 locations (see Figure 1C) over one year with two campaigns per season, from spring of 2013 through spring of 2014. From the total of salinity and temperature data obtained by profiles during the campaigns, a TS diagram was generated for the characterization of water masses in the region, using as a benchmark the work of Castro et al. (2006).

The presence of four masses of water was found by the thermohaline characteristics measured at the study area. The conditions during the spring and summer period were characterized by the interaction of at least three water masses, with ACAS (Portuguese acronym for Central Water of South Atlantic) occurring in the lower vertical extracts and AT (Tropical Water) occurring at the upper extracts especially at sample points $8,9,12$ 13, 14 and 15 (see Figure 1C). The same occurs at ST10 and ST11, but only in one sampling campaign. Such a thermocline has not been verified at stations 3, 4, 5, 6 and 7, thus showing no intrusion of denser water masses from deeper layers. It was found that the AC (Coastal Water) occurred in the surface layers of these and other points, being sometimes influenced by fluvial discharge that was able of reducing 5 PSU from the salinity of surface, mixing with the AP water mass (Platform Water), which was present especially in autumn and winter.

\section{NUMERICAL MODELING}

The processes of substance mixing, transport and degradation resulting from wastewater systems in coastal regions can be divided in two regions: near and far field. The first one is the zone of initial dilution, where the effects of the discharge prevail. The second is the region where the dynamics of the water body, as tidal currents, as well as bio-chemical reactions and substance degradation, govern the plume water quality behavior. The different dynamics of near and far field implies the necessity of distinguished models.

\section{LARGE SCALE COASTAL WATER QUALITY MODELING (FAR-FIELD)}

For the far field numerical modeling the Delft3DFLOW model (Deltares, 2011a) was used. The hydrodynamic model was set up with 5 vertical sigma layers, including the processes of winds, salinity and temperature. The model was forced with predicted astronomical tide, measured winds, precipitation, fluvial discharges and meteorological tide, and salinity and temperature data provided by the global ocean model Hycom (Hybrid Coordinate Ocean Model). The model was run for one entire year. Water level and currents were calibrated and validated with measured data of the three ADCP stations, and salinity and temperature 
profiles were validated using the 15 measurementt stations. Figure 4 illustrates the hydrodynamic validation results for station 17 (Ingleses), for the surface layer during fall season.

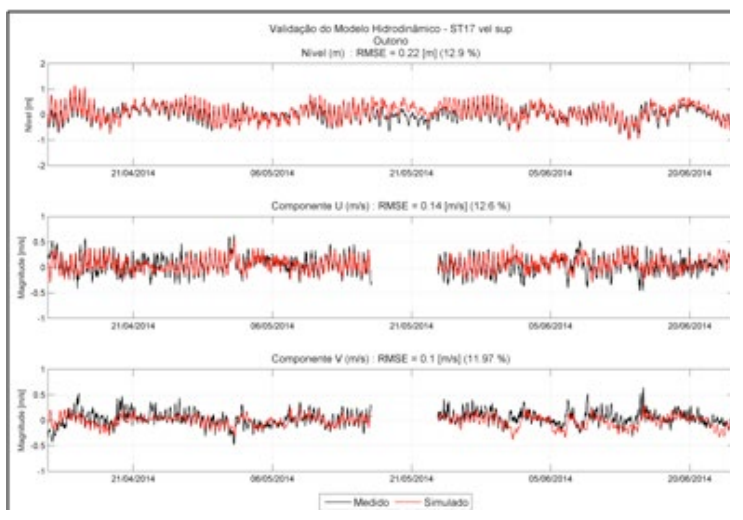

Figure 4. Hydrodynamic validation results for station 17 (Ingleses), Surface layer, fall season. Water level [m] (superior), $U$ velocities [m/s] (middle) and V velocities [m/s] (inferior). Black - measured; Red - simulated.

\section{DISCHARGE DISPERSION MODELING (NEAR -FIELD)}

The outfall is a pipeline or tunnel from the wastewater treatment plant to the receiving water, which terminates in a diffuser that efficiently mixes the effluent in the receiving water. It thus follows two main principles: (1) locate the disposal area into environmentally less sensitive, and antropogenically less used, offshore regions, which in addition have higher mixing and assimilative characteristics, and (2) enhance the initial mixing by multiport diffuser systems, providing efficient and fast initial mixing in a limited zone that reduces pollutant levels to ambient standard requirements, and facilitates the natural assimilative processes.

The mixing zone expert system CORMIX (DONEKER, R.L. \& JIRKA, 2007) has been used in this study. Based on an integral method for near field, it contemplates situations of single port, multiport diffusers and surface discharges. It was developed in cooperation of several institutions, among them the U.S.EPA (Environmental Protection Agency), Cornell University, Oregon Graduate
Institute and MixZon. It makes qualitative analysis with length scales (empirical method, where the boundaries are considered) selecting a - flow class that can identify a key aspect. The quantitative analysis is made by the submodule Corjet (Buoyant Jet Integral Model). Besides the plume geometry, CORMIX simulates the initial dilution (DONEKER \& JIRKA, 2007).

Due to the process complexities in the near-field the model however considers only steady state conditions, although the environment is unsteady. To overcome that limitation, a time series approach has been employed running the near-field model for hundreds of times. CorTime is the herefore developed post-processing tool of CORMIX.

The far field hydrodynamic numerical model results for one year simulation were used to provide input data to the near field model Cormix. Those were ambient velocity and density distributions.

The main output of CorTime is the Status Report, where the characteristics of the modeled plumes are summarized for each time step. They are the plume central line coordinates at the end of the near field and at the end of the regulatory mixing zone, its dimensions, dilutions, concentrations and the travel time until this point. Those results were post-processed for near-field dilution mapping as shown in Figure 5 for further analysis (Ishikawa et al., 2016).

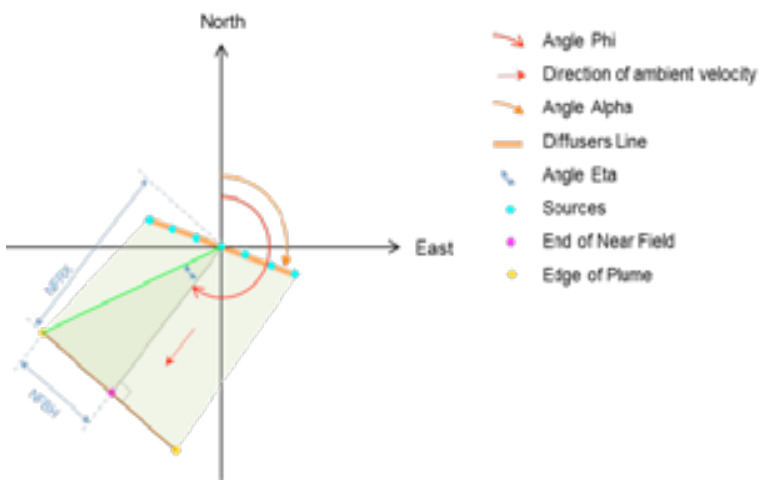

Figure 5: Scheme adopted to interpolate the dilution of plumes at the near field region 
The NFRX is the distance from the source to the end of the near field region towards to the ambient velocity (indicated by the angle phi, counted clockwise from the geographic north), and the NFRBH is the half-width of the plume. With these two lengths a right triangle is defined, and the coordinates of the corners are defind. The sources are matched as zero dilution, the corners and the NFRX point are matched with the final solution simulated by CORMIX. After that the dilution of the whole plume is set by a simple interpolation.

\section{RESULTS AND DISCUSSION: ASSESMENT OF ALTERNATIVES}

Effective wastewater management systems are combined systems using the optimal technology blend between wastewater treatment and discharge technologies, latter being related directly to the assimilative capacities of the receiving waters.

Depending on the substance of concern, required wastewater treatment levels and discharge dilution rates can vary considerably. Some (such as BOD) can be achieved by treatment or dilution on its own, others, such as bacteria, require a blend of both technologies (see table 1).

\section{NEAR-FIELD MIXING RESULTS FOR}

\section{ALTERNATIVE WITH PRE-TREATED EFFLUENT}

The harmonic mean dilution around the source, resulted from the near field model is visualized in Figure 6. For a long outfall at Rio Vermelho, the mean dilution is $380: 1$. The last contour line in Figure 6 represents this value. Within an arbitrarily defined regulatory mixing zone of $200 \mathrm{~m}$ there is at least a dilution of 350:1. The size of this zone is usually defined by regulators, however, often being proportional to several times the local water depth (Bleninger and Jirka, 2011). The dilution requirements (compare with table 1) for all but bacteria were much lower than the computed dilutions showing the effectiveness of the outfall in combination with a large receiving water body.

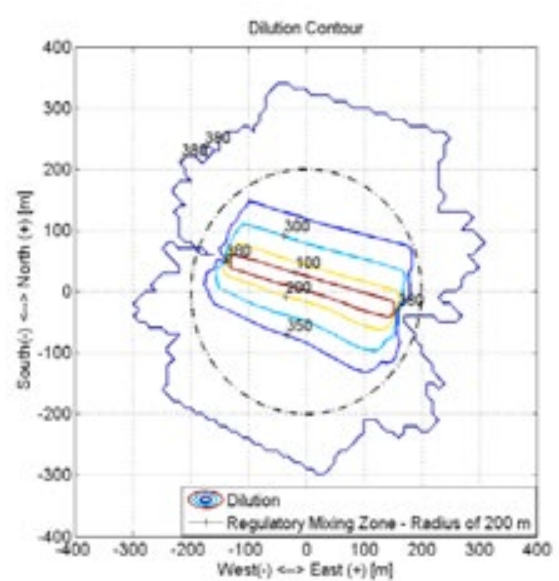

Figure 6: Harmonic mean dilution around the source for Rio Vermelho with a long outfall

This calculation has been applied to all potential alternatives, and results are shown in Graph 1 by comparing only mean dilutions of each alternative.

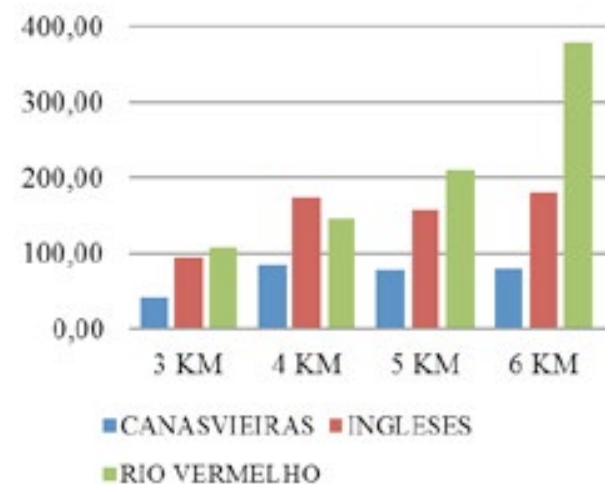

Graph 1: Harmonic mean dilution for the possible locations of the submarine outfall

To provide further guidance and support for decision making, the exceedance frequency is shown in Figure 7 for a long outfall solution at Rio Vermelho, for BOD. It was idealized that a dilution of 10:1, as shown in Table 1, was necessary to be in compliance with the ambient standards.

The variation of outfall locations using the post-processing method shown here allows to visualize exceedance frequencies of water quality standards for different discharge sites (see Figure 8). Both locations shown were in compliance with the imposed requirements, and the longer outfall showed higher efficiency than the shorter outfall. 


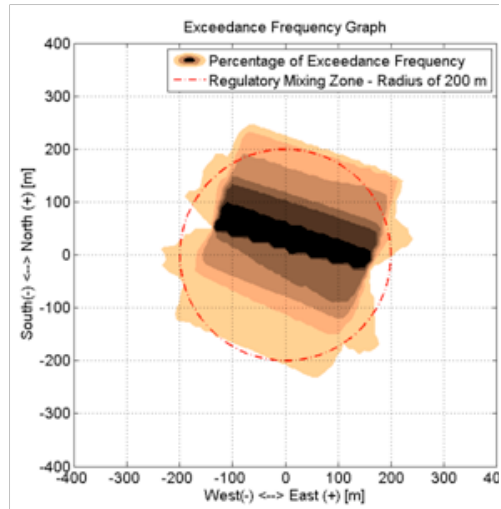

Figure 7: Exceedance frequency for BOD for a long outfall at Rio Vermelho.

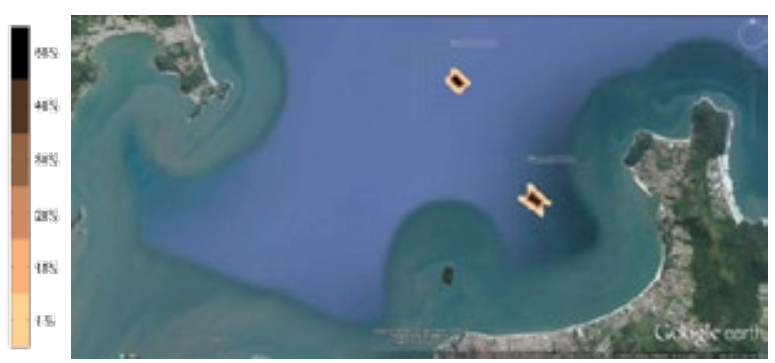

Figure 8 : Exceedance frequencies of BOD concentrations for two scenarios with different outfall lengths for pre-treated wastewater discharging at Canasvieras.

However, the results clearly show that the dilution rates are still too low to be in compliance with required dilutions for bacteria. Thus, near-field mixing alone is not sufficient to achieve bathing water criteria. Therefore, an additional analysis is required for the far-field region (i.e. beaches and environmentally protected areas), and including bacterial decay and water quality processes as described as follows.

\section{FAR-FIELD WATER QUALITY MODELING FOR DIFFERENT ALTERNATIVES}

Currently there are four wastewater treatment plants in the north of the Island that will be inte- grated to the outfall disposal system. The E.Coli concentration according to CASAN, for each season (spring, summer, fall, winter) are of the order of 107 and 108 MPN/100 ml E.Coli concentration.

The results from the near-field model were used for the studied cases as source for the water quality model Delft3D-WAQ (Deltares, 2011b), which was applied for the three locations (and a short and long outfall solution) for a one year period to simulate dissolved oxygen, Chemical oxygen demand (COD), biochemical oxygen demand (BOD), nutrients and bacteria (E.Coli), considering primary and secondary treatment based on typical wastewater parameters according to Von Sperling (2005). The processes considered were mineralization of organic matter, reaeration, nitrification and ammonification. Temperature and salinity data inputs were obtained from the hydrodynamic model.

Results for nutrients and oxygen demand indicated a low oxygen demand and compliance with legislation regarding COD and BOD. However, even though the near-field results indicated sufficient nutrient dilution also at Canasvieiras, the nutrient build-up, due to limited flushing capabilities at that location, can be shown in the far-field model indicating the possibility of nitrate and phosphate accumulation inside the northern and southern bay (Figure 9top). Phosphate concentrations consequently are also being higher than required by environmental legislation. Thus, Canasvieras site has been discarded as alternative.

Figure 9 shows the results for phosphate concentration after 10 months of simulation for Canasvieras and Rio Vermelho for primary treatment and maximum effluent discharge $\left(3,07 \mathrm{~m}^{3} / \mathrm{s}\right)$. 


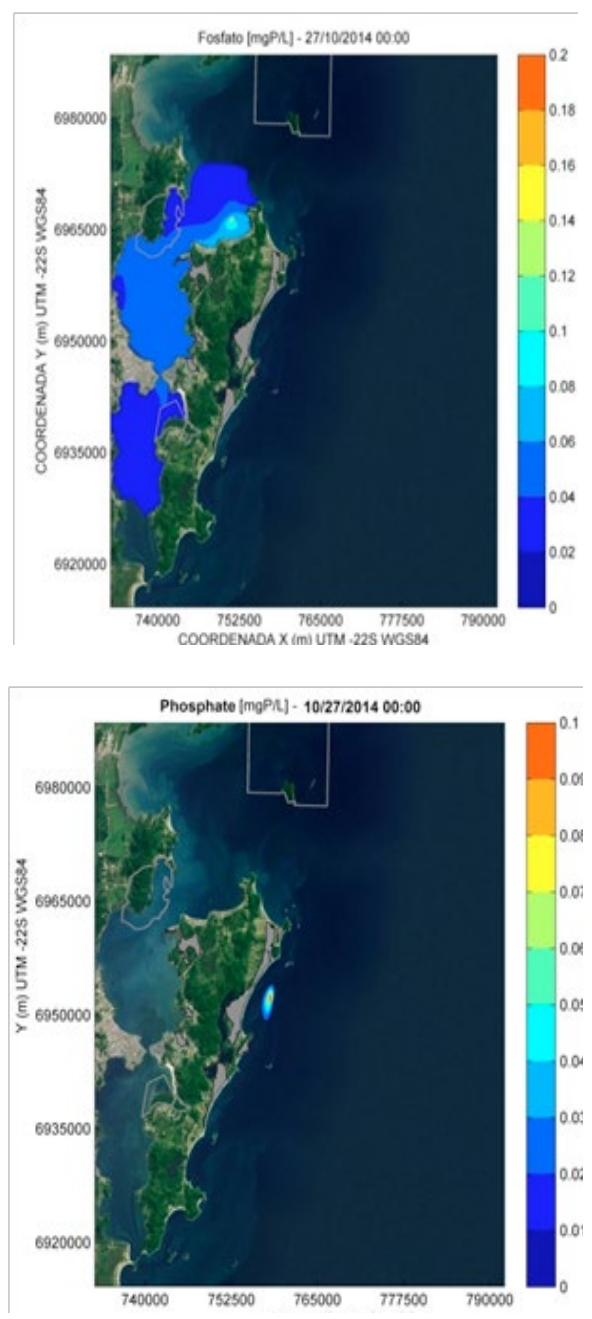

Figure 9. Phosphate concentration after 10 months of simulation for primary treatment and maximum effluent discharge $\left(3.07 \mathrm{~m}^{3} / \mathrm{s}\right)$. Top: Canasvieras. Down: Rio Vermelho.

The bacteria decay simulation using Delft3DWAQ is done according to the Mancini (1978) formulation. After a sensitivity analysis, it was used a default UV extinction coefficient of $3 \mathrm{~m}-1$ and a variable solar radiation based on representative one year measured values.

Brazilian environmental legislation stipulates that at general purpose saline waters E.Coli can be used as a representative parameter, and satisfactory water quality is represented if $80 \%$ of the time E.Coli concentrations are lower than 800 MPN/100 $\mathrm{ml}$. In addition, there should be no occurrence of concentrations higher than $2000 \mathrm{MPN} / 100 \mathrm{ml}$.
Figure 10 presents probability maps (\%) of E.Coli concentrations higher than $800 \mathrm{MPN} / 100 \mathrm{ml}$ for Ingleses for a discharge of $3.07 \mathrm{~m}^{3} / \mathrm{s}$ and an initial E.Coli concentration of $107 \mathrm{MPN} / 100 \mathrm{ml}$ (primary treatment), with a short outfall. The yellow line indicates an offset distance of 200 meters from the coastline. The red line indicates the furthermost occurrence of 2000 MPN/100 ml E.Coli concentration. Values lower than $1 \%$ were not visualized.

Further simulations were performed extending the outfall length in order to look for a feasible alternative for other treatment levels. However, the results showed that a longer outfall increases the risk of the plume reaching Arvoredo Marine Biologic Reserve, and even higher treatment levels were not able to keep the plume off the coast continuously, as it was possible for a simpler configuration for Rio Vermelho.

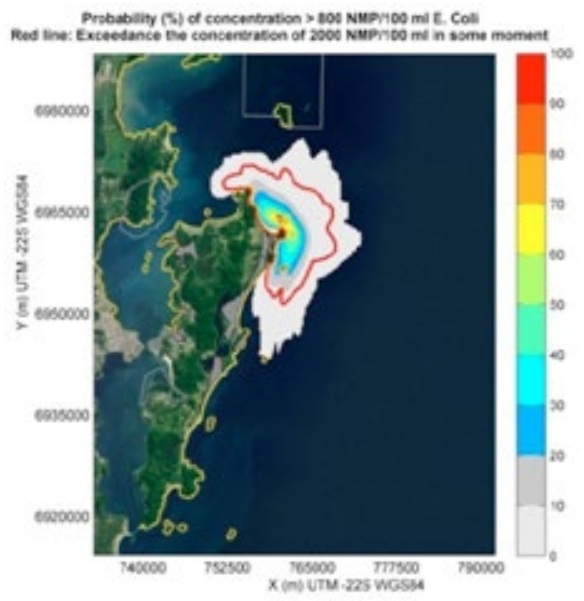

Figure 10. Probability maps results (\%) of E.Coli concentration higher than $800 \mathrm{MPN} / 100 \mathrm{ml}$ for Ingleses, discharge: $3.07 \mathrm{~m}^{3} / \mathrm{s}$; E. Coli effluent concentration: $107 \mathrm{MPN} / 100 \mathrm{ml}$ (primary treatment); short outfall. Yellow line: 200 meters offset from coastline. Red line: furthermost occurrence 2000 MPN/100 ml E.Coli concentration. Gray color: permitted by environmental legislation.

Figure 11 presents probability maps (\%) of E.Coli concentrations higher than $800 \mathrm{MPN} / 100 \mathrm{ml}$ and a exceedance time map (days) where E.Coli concentrations are higher than 800 MPN/100 ml for discharge of $3.07 \mathrm{~m}^{3} / \mathrm{s}$ and E. Coli concentration of 
$107 \mathrm{MPN} / 100 \mathrm{ml}$ (primary treatment), with a long outfall at Rio Vermelho. Same in Figure 12 for secondary treatment.
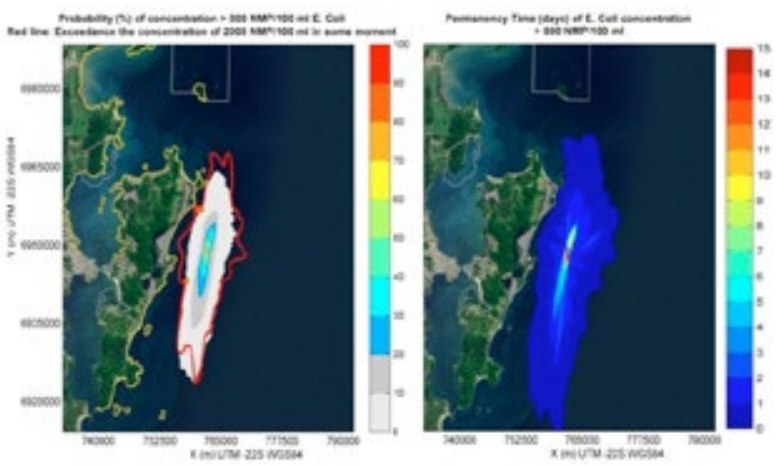

Figure 11. Rio Vermelho probability maps results (\%) of E.Coli concentration higher than 800 MPN/100 $\mathrm{ml}$ (left) and exceedance time (days) when E.Coli concentration is higher than $800 \mathrm{MPN} / 100 \mathrm{ml}$ (right). Discharge: $3.07 \mathrm{~m}^{3} / \mathrm{s}$; E.Coli effluent concentration: 107 MPN/100 ml (primary treatment); long outfall. Yellow line: 200 meters offset from coastline. Red line: furthermost occurrence 2000 MPN/100 ml E.Coli concentration. Gray color: permitted by environmental legislation.

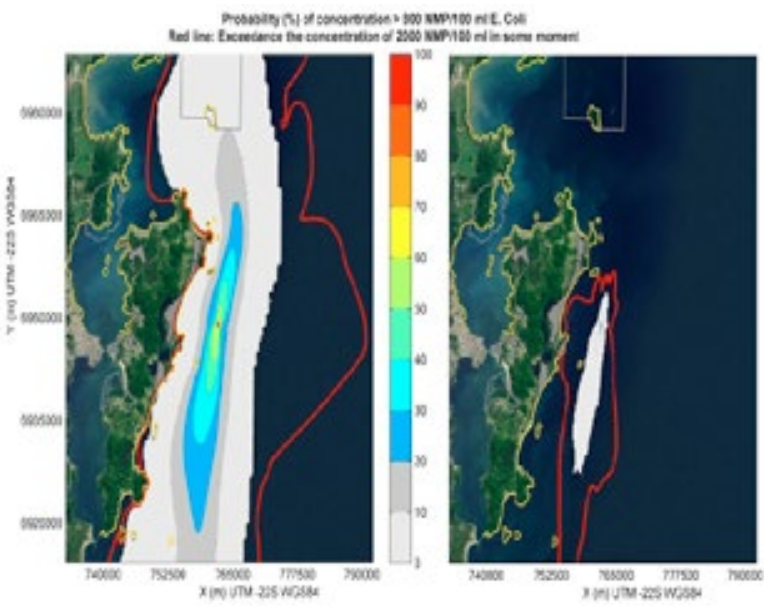

Figure 12. Probability maps results (\%) for discharge of $3.07 \mathrm{~m}^{3} / \mathrm{s}$ : secondary treatment, and long outfall. Gray color: permitted by environmental legislation.

\section{CONCLUSIONS}

The combined utilization of screening methods, field measurements, and numerical modeling techniques showed that there is no unique modeling or design approach, and no unique solution, satisfying all boundary conditions and con- straints. However, the combined approach clearly showed strengths and weaknesses of the applied techniques and their advantage when using them together in the decision-making process.

Regarding the studied case of Santa Catarina Island, 42 alternatives have been defined in the screening analysis. The field measurements, complemented with the basecase numerical modeling allowed to understand and quantify ambient water characteristics at the surroundings of the potential treatment and discharge sites. The TOPSIS methodology was efficient in funneling possibilities and showed consistent results compared with the best alternatives obtained after field studies and numerical modeling.

Combined with near field and far field numerical modeling, TOPSIS proved to be an efficient strategy towards a multipurpose best alternative screening. In addition, the participation of several sanitation specialists in the topsis phase provide them to be integrated do the project in a broader perspective and to have a better understanding of each criterias importance in the final decision. Furthermore, the application of multiple analysis (Field measurements, TOPSIS, numerical modeling) and the participation of specialists from different areas, provides more confidence to the decision maker board towards the chosen alternative.

Results indicate are clear tendency to Rio Vermelho being the most effective solution with either a long outfall and primary treatment or a shorter outfall with. secondary treatment. The numerous near-field simulations allowed to optimize the outfall design to achieve fast initial mixing after short regions, achieving dilutions much higher than required for all substances, except bacteria. The farfield water quality simulations used the output from the near-field model to verify flushing and decay characteristics of nutrients, and bacteria for bathing water analysis. The numerical model results provided hereby a deeper evaluation of the 
exceedance frequency that would not be acquired with standard water quality field measurements.

The results however still require further decision making to find the best blend of minimum required treatment under given and highly variable operational conditions. This final decision depends more on strategical criteria at all levels (sanitation company, state government, environmental agency and stakeholders). It is hereby very important to integrate all in the process towards the final decision in order to combine feasible cost alternatives with minimum environmental impact.

\section{REFERENCES}

ARULDOSS, M.; LAKSHMI, T. M.; VENKATESAN, V. P. 2013. A survey on multi criteria decision making methods and its applications, American Journal of Information Systems 1(1): 31-43

Barletta, R., Ribeiro, P., Falkenberg, A., Maranhão, M., Franklin, L., Benedet, L., De Lara, P., Trevisan, A., dos Santos, V., Bleninger, T., Physical Oceanographic Measurements to Support the Outfall System Design in the North of Santa Catarina Island, Brazil, Proc. Intl. Symp. on Outfall Systems, Ottawa, Canada, 1013.05.2016

BLENINGER, T. Coupled 3D hydrodynamic models for submarine outfalls: Environmental hydraulic design and control of multiport diffusers. 2006. 219 f. Dissertation (PhD in Hidraulic Engineer) - Karlsruher Institut für Technologie, KIT, Germany, 2006

BLENINGER, T., JIRKA, G.H. Mixing zone regulation for effluent discharges into EU waters, Proceedings of the ICE - Water Management, 165, 2011

BLENINGER T., 2012, Desalination and Water-Reuse: Demand for Hydro-Environment Engineering and Research, IAHR, Hydrolink 1, 2012

BLENINGER, T., ROBERTS, P. Outfall Systems, Chapter in: IWA Specialist Group Directory Global Trends \& Challenges in Water Science, Research and Management A compendium of hot topics and features from IWA Specialist Groups, ISBN: 9781780401065 , p. 37-42. 2012

Castro, B. M.; Lorenzzetti, J. A., Silveira, I. C. A.; Miranda, L.B. 2006. Estrutura Termohalina e Circulação na Região entre Cabo de São Tomé (RJ) e o Chuí (RS) In: Rossi-Wongtschowski, C. L. D. B. \& Madureira, L. S. P. (Orgs.), O Ambiente Oceanográfico da Plataforma Continental e do Talude na Região Sudeste-Sul do Brasil. São Paulo: Edusp. p. 11-120.
CONSELHO NACIONAL DO MEIO AMBIENTE - CONAMA. Resolução n. ${ }^{\circ}$ 274, de 29 de Novembro de 2000 - Define os critérios de balneabilidade em águas brasileiras. 2000.

CONSELHO NACIONAL DO MEIO AMBIENTE - CONAMA. Resolução n. ${ }^{\circ}$ 357, de 17 de Março de 2005 - Estabelece os padrões para o lançamento de efluentes líquidos. 2005.

CONSELHO NACIONAL DO MEIO AMBIENTE - CONAMA. Resolução n. ${ }^{\circ}$ 430, de 13 de Maio de 2011 - Dispõe sobre as condições e padrões de lançamento de efluentes. 2011.

DELTARES, 2011a. Delft3D - FLOW User Manual, 3.15 ed. Delft, The Netherlands.

DELTARES, 2011b. Delft3D - WAQ User Manual, 4.03 ed. Delft, The Netherlands

DONEKER, R.L. \& JIRKA, G.H. CORMIXUser Manual: A Hydrodynamic Mixing Zone Model and Decision Support System for Pollutant Discharges into Surface Waters, EPA-823-K-07-001, Dec. 2007.

Falkenberg, A., Barletta, R., Franklin, L., Ribeiro, P., De Lara, P., Bleninger, T., Trevisan, A., Dos Santos, V., Optimizing Outfall System Configurations using Decision Support and Numerical Models. Case Study of Santa Catarina Island, Brazil, Proc. Intl. Symp. on Outfall Systems, Ottawa, Canada, 10-13.05.2016

IPUF. Florianópolis: dinâmica demográfica e projeção da população por sexo, grupos etários, distritos e bairros (1950-2050). Instituto de Planejamento de Florianópolis (IPUF), 2007.

ISHIKAWA, M.,et al. Method to classify and visualize time series simulations of submarine outfalls. Proc. Intl. Symp. on Outfall Systems, Ottawa, Canada, 10-13.05.2016

MANCINI, J.L., 1978. Numerical estimates of coliform mortality rates under various conditions. Journal Water Pollution Control Federation 2477-2484

PMF. Plano Municipal Integrado de Saneamento Básico - PMISB. Prefeitura Municipal de Florianópolis (PMF), 300p, 2011

ROBERTS, P.J.W., SALAS, H.J., REIFF, F.M., LIBHABER, M., LABBE, A., THOPSON, J.C., 2010. Marine Wastewater Outfalls and Treatment Systems. International Water Association, London

SANTOS, A. \& COSTA, S. W. Síntese Informativa da Maricultura 2014. Governo do Estado de Santa Catarina, Secretaria de Estado da Agricultura e da Pesca, Empresa de Pesquisa Agropecuária e Extensão Rural de Santa Catarina. 8p. 2014.

VON SPERLING, 2005. Introdução à qualidade das águas e ao tratamento de esgotos. Ed: Departamento de Engenharia Sanitária e Ambiental, UFMG. 243pg

WORLD BANK. Wastewater and Ambient Water Quality . Occupational Health, 2007. 